DOI: https://doi.org/10.25217/jcd.v1i2.1826 | Accepted 23'Agus 2021 | Published 30'Sept 2021

\title{
The Role of Counseling Guidance in Early Childhood Education and Their Emotional Development
}

\author{
Kushendar \\ ushenefrans@gmail.com \\ Institut Agama Islam Ma'arif NU (IAIMNU) Metro Lampung \\ Zara Mayra \\ zaramayra@gmail.com \\ Universitas Negeri Semarang
}

\begin{abstract}
Emotion is a form of essence of the embodiment of human feelings, It can change the atmosphere for the better or worse. The negative emotion of anger is not liked and is not allowed by Islam. The purpose of this study was to determine the role of guidance and counseling in early childhood. The method used in this study is a qualitative research method. The subjects in this study were eight early childhood students aged 4-7 years. The techniques used in collecting research data are interview techniques, observation techniques, and documentation techniques. The data analysis used in this research is descriptive qualitative data analysis. The results of this study indicate that the group counseling carried out by the researcher went through four stages, namely the formation stage, the intermediary stage, the activity stage and the termination stage. So it can be concluded that the role of guidance and counseling can be one of the right ways to overcome angry emotions in students.
\end{abstract}

Keywords: content; formatting; article.

(C) 2021 Kushendar, Zara Mayra

This work is licensed under a Creative Commons Attribution-ShareAlike

\section{INTRODUCTION}

Emotions are feelings that have a lot of impact on behavior. Usually emotions are reactions to impulses from outside and within the individual. Emotions are related to physiological changes and various thoughts. So, emotions are one of the important aspects in human life. Emotion is a complex reaction that relates to a high level of activity and changes in depth, and is accompanied by strong feelings, or accompanied by an affective state (Desmita, 2010: 116).

According to Hurlock, social emotional development is the development of behavior in accordance with social demands, where emotional development is a process in which children train social stimuli, especially those obtained from group 
demands and learn to get along and behave. In learning activities at school we are faced with a number of characteristics in students with different and diverse characters. There are those who can take the learning process smoothly and successfully without experiencing difficulties, but on the other hand not a few students who actually experience various difficulties in learning (Kushendar, K., \& Maba, A. P. (2017).

Karin Villien, an early childhood education consultant from the World Bank, revealed that learning activities in early childhood education in Indonesia are more academic in nature where children sit mostly on benches like in elementary school. This opinion implies that learning in this country's PAUD is still lacking in character education and tends to highlight the intellectual aspect. Furthermore, Karin Villien said that children are rarely given the opportunity to explore and do what they are interested in doing on their own. "Many educators do not provide opportunities for children to think and educators do not provide opportunities for children to express their feelings and find solutions to their own problems" (Yufiarti, 2002: 61).

The learning process at this time affects the development at the next stage. The period of infant development until entering elementary school becomes a strong learning "foundation" for children to develop their social-emotional abilities to be healthier and children are ready to face the next more complicated stages of development. At this stage of crisis, it is the right time to lay the foundations for developing social emotional abilities (Briggs, 2012).

Social development is the development of behavior in children where children are asked to adapt to the rules that apply in the community. In other words, social development is a child's learning process in adjusting to norms, morals and traditions in a group (Yusuf in Yahro, 2009). Piaget showed a high egocentric nature in children because children have not been able to understand the different perspectives of other people's thoughts (Suyanto, 2005). At this stage the child only cares about himself and has not been able to socialize well with others. Children do not understand that the environment has a different perspective from themselves (Suyanto, 2005). Children still do everything for themselves not for others.

In line with the development of scientific studies, the definition of guidance at this time has also changed, although by not leaving its essence as a process of providing assistance activities (helping relationship). Muro \& Kottman (Nurihsan, 2003: 11) explained that the currently developing guidance is developmental guidance. The vision of guidance is educative, developmental and outreach. Educational because the emphasis of guidance services is on prevention and development, not corrective or therapeutic, although these services are also not neglected. Development because the orientation of the guidance target is the optimal development of all aspects of the individual's personality with efforts to facilitate development through engineering the developmental environment. Outreach because the target population of guidance services is not limited to problematic individuals but all individuals regarding all aspects of their personality in all contexts of their lives (problems, intervention targets, settings, methods, and length of service). 


\section{METHODOLOGY}

The researcher examines the "Role of Guidance in early childhood education and emotional development". The purpose of this study was to find out how group counseling to overcome negative emotions and seen in the aspects of development and education. The method of this research is qualitative research where according to Sulistyo and Basuki (in Prabowo and Hariyanto, 2013), this research is research related to ideas, perceptions, opinions, beliefs of people to be studied and all of them cannot be measured by numbers. The subjects in this study were 8 PAUD students in the city of Bogor who were selected by purposive sampling.

In this study, data collection techniques using interview, observation and documentation techniques. The interview technique is a means of re-checking or proving the information or information previously obtained by Rahmat (2009). Then, data collection was also carried out with documentation techniques which according to Subandi (2011) this technique is useful to help display some data that may not have been obtained. Meanwhile, in this study, the data were analyzed using qualitative descriptive analysis techniques.

\section{RESULTS AND DISCUSSION}

According to Crow \& Crow (M. Surya, 1988: 45) guidance is defined as assistance provided by a person, both a man and a woman who has a good personality and adequate education to an individual of any age to help him, develop his own life activities, make his own choices. , and carried his own burden. Based on the opinion of experts about the concept of guidance and counseling, guidance and counseling in early childhood can be interpreted as an effort to help teachers / assistants to early childhood so that children can grow and develop optimally and be able to overcome the problems they face.

Regarding the principles and principles of guidance and counseling for early childhood, Syaodih, E. (2003: 79) explains that in the implementation of guidance services for early childhood, it is necessary to pay attention to the following principles which are adjusted to the stages in counseling.

1) Initial stage (formation)

At this early stage, the group leader accepts the presence of group members warmly and happily. Beginning with saying basmallah lafadz and greetings, the counselor opened this group counseling activity. After that, the group leader did not forget to express his deepest gratitude to the group members who were present. Then, the next step is to pray. The group leader then explains the nature of group guidance, and introduces both group leaders and group members.

2) Transition stage

In the transitional stage, the counselor creates a warm and comfortable atmosphere and invites group members to build trust together. The counselor explained again about group guidance. Then the counselor asked the members about their readiness to continue the activity. In this stage, the counselor tries to identify the group atmosphere and provides examples of fun games or ice breaking so that students can be enthusiastic about guidance activities.

3) Activity stage

At this stage, the first step is to give group members the opportunity to present their respective problems in turn. Next, make an agreement about what was 
discussed, with students, AC, BD, KH, TE, MM, LO, GH, JK In this case, explaining about Guidance is an Important Part of the Educational Process The educational process is not a process of intellectual development alone, but a process of development of all aspects of the child's personality because the child's personality cannot be divided into certain pieces. Education is also not a process of equating children's development, but the process of developing the abilities possessed by children to develop the totality of their personality as personal, social and God's creatures. The presence of guidance in educational practice is not enough to be associated with the teaching process but also needs to be linked to various other activities that support the growth and development of children.

4) Termination stage

This is the last stage of the group counseling implementation where the counselor suggests that the activity will end soon. The group leader invites group members to express their impressions and assessments of the progress achieved by each member. Then, proceed with discussing what activities will be carried out next. Then, group members are invited to express their messages and responses. Not to forget, the group leader thanked all group members.

Guidance Is Provided to All Children and Not Only to Children Who Face Problems All students need assistance, whether they are considered to have no problems or children who are facing problems. Children who are considered to have no problems, but still need guidance because children need to continue to develop the abilities that exist in themselves. Assistance given to children like this is preventive and developmental. Meanwhile, guidance for children with problems is more corrective.

Guidance is an Unified Process in All Educational Activities Guidance is one of the educational activities in addition to teaching and training. Implementation of guidance in early childhood can not be separated in the whole learning process. When the teacher carries out teaching and training activities, at that time the teacher can carry out the guidance process using learning methods that are often used in teaching.

Guidance Must Be Child-Centered Being Guided Clarity of direction to whom the guidance process is carried out will bring about good results from a process carried out. Teachers should not carelessly provide guidance, the guidance carried out by the teacher must be based on an understanding of the problem conditions of the children they are guiding. Guidance Activities cover all child development abilities which include physical-motor abilities, In addition to developing the potential of students and recognizing children's abilities, through counseling guidance, children's mental and social development are also prepared from an early age to be able to adapt when they have to continue to higher education institutions. If in a higher environment counseling guidance is needed, then in PAUD, counseling guidance is also needed because of the equality of PAUD with primary and secondary education (in Astutik, C, 2018)

\section{CONCLUSION}

Social development is the level of interaction of children with other people, ranging from parents, siblings, playmates, to society at large. While emotional development is an overflow of feelings when children interact with other people. 
Thus, socio-emotional development is a child's sensitivity to understand the feelings of others when interacting in everyday life.

Developing emotional-social relationships is an important milestone for children. For many children, socializing is the first-time experience of having to talk deals with their peers. Although children their age still engage in parallel play, they are increasingly interested in playing with other children.

The counseling guidance program is actually a program that is not only important in middle and high school levels, but is equally important to be implemented in schools from an early age because in addition to helping early childhood children to develop according to their interests, talents and potential optimally, this program also aims to prevent problems that may arise in children in their development period as early as possible.

\section{ACKNOWLEDGEMENT}

If you need affection for a particular party, such as a research sponsor, state it clearly and concisely, avoiding flowery expressions of gratitude.

\section{REFERENCES}

(Bibliography of at least 15 references to DOI journal articles and using reference applications, for example Mendeley, Zetero and others)

Astutik, Choli. 2018. Penerapan Layanan Bimbingan dan Konseling Pada Anak Usia Dini. Alpen: Jurnal Pendidikan Dasar Volume 2 no.2. ISSN 2580-6890

Briggs, R. D. (2012). The Importance of Social Emotional Development in Early Childhood. Pediatrics For Parent, 28, 11 \& 12, 15

Desmita. 2010. Psikologi Perkembangan. Bandung: PT. Remaja Rosdakarya

Hurlock, Elizabeth B. 1996. Perkembangan Anak Jilid I, Edisi keenam. Jakarta: Erlangga.

Kushendar, K., \& Maba, A. P. (2017). Bahaya Label Negatif Terhadap Pembentukan Konsep Diri Anak Dengan Gangguan Belajar. Nidhomul Haq: Jurnal Manajemen Pendidikan Islam, 2(3), 106-113.

P. Daeng dan Pujiana, Perkembangan Anak Usia Dini (Jakarta: Rineka Cipta, 2005), h. 31

Susanto, Ahmad. 2011. Perkembangan Anak Usia Dini:Pengantar dalam Berbagai Aspeknya. Jakarta: Kencana

Santrock, W. J. (2007). Perkembangan Anak. Jakarta: Erlangga

Syaodih, Ernawulan (1999). Peranan Bimbingan Guru, Pengasuhan Orang Tua, dan Interaksi Teman Sebaya terhadap Perkembangan Perilaku Sosial Anak Taman Kanak-kanak. Tesis PPs IKIP Bandung (tidak diterbitkan).3

Yufiarti. (2003). Karin Vilien tentang: Pembelajaran di Taman Kanak-Kanak Indonesia. Buletin PADU Jurnal Ilmiah Anak Dini Usia Edisi Perdana.

Yusuf, Syamsu. 2001. Psikologi Perkembangan Anak dan Remaja. Bandung: PT Remaja Rosda Karya 